\title{
To the Government and Parliament of the Republic of Groatia
}

\author{
An address by the Institute of Public Finance to \\ members of the Government and Parliament
}

GENERAL NOTES

The purpose of this address is to inform newly-elected Members of Parliament and the new Government members on the Institute of Public Finance's views on key issues concerning public sector economics and public finances. The Government and Parliament are faced with very serious challenges of implementing structural reforms that are crucial for boosting economic growth and correcting fiscal imbalances. With the support of Parliament, the Government will have to formulate effective shortterm and long-term reform strategies, plans and programmes and insist on their implementation, despite the expected interest group resistance. No one involved in this should expect to be celebrated or popular, but the only way out of the country's economic crisis is through thorough structural reforms toward a more efficient public sector and economy in general, fiscal consolidation and higher competitiveness, employment levels and economic growth.

The country is faced with serious difficulties. Following a cumulative fall in real GDP of over 12\% from end-2008 to end-2014, GDP is expected to grow by as little as about 1\% in 2015. The national budget deficit is high (about 5\% of GDP in 2015) and public debt (about 90\% of GDP in 2015) difficult to sustain. This is accompanied by a high unemployment rate (about 16\% in 2015) and low employment (as little as about $43 \%$ of persons aged I 5 + were employed in 20I4). The consequences of the global economic crisis can hardly be used as an excuse anymore, because not only that the country's economic and fiscal indicators are markedly worse than the EU Member States' average, but Croatia ranks the lowest of almost all European countries in these terms.

The Institute of Public Finance (IPF) is a public research institute focused on the economic, legal and institutional aspects of public finances and public sector. Besides its basic scientific activities and in order to promote better and more complete understanding of public sector economics and public finances, and to increase public sector transparency, government accountability and citizen participation, the Institute regularly publishes independent expert analyses, opinions and suggestions, written for the general public which point to the necessary prerequisites for reasoned discussions to be held before making crucial decisions. 
Instead of promoting the necessary conditions for fiscal consolidation and economic development, i.e. depoliticization, democratization, deregulation, decentralisation, liberalisation and transparency, previous governments have done just the opposite. Decisions have mainly been made within a narrow circle of like-minded political supporters, resulting in partial rather than comprehensive interventions, most frequently on the revenue and not on the expenditure side of the budget. As the economic and fiscal effects and consequences of law enforcement have not been assessed, it is not known whether the implemented fiscal measures and government incentives were effective and whether they yielded the expected social and economic results. All this has led to inefficient management of public funds, public companies and public sector as a whole. The consequences of this are unreformed public administration, health care, pension insurance, education and social welfare systems, and a large share of tax and non-tax revenues and public sector in GDP.

All this is reflected in the aforementioned poor macroeconomic indicators. Even though all governments so far declared themselves in favour of the reforms, at least paying lip service to the recommendations, suggestions and requirements coming from the European Commission, IMF and World Bank, the reforms were simply not implemented. A new Government is expected to discontinue partial, uncoordinated, unfounded and inadequately planned measures and, with the support of Parliament, identify the national strategic priorities, prudently manage public finances, enforce reforms of the country's territorial and fiscal organisation and reforms of the tax, public investment, state aid, pension, and health care systems, as well as education and social welfare systems. It is vital to focus on the expenditure and not only to the revenue side of the budget. All the reforms must be explained to the public, because even the best-designed reform cannot succeed without public understanding and support.

The text below presents brief recommendations for areas considered by the IPF as particularly important for improving the efficiency of the public sector and economy, fiscal consolidation, and increasing competitiveness, employment and economic growth. More detailed information on some other interesting topics not dealt with in this article, but also on all the issues, only briefly mentioned in the text, can be found in the relevant newsletters, press releases and other publications issued by the IPF.

\section{FORMULATION OF STRATEGIC DEVELOPMENT PRIORITIES}

As an EU member state, Croatia is required to participate in the implementation of the Europe 2020 Strategy (EU 2020), and it also participates in the Southeast Europe Development Strategy 2020 (SEE 2020). Regretfully, the country still lacks a single national development strategy. Implemented instead are the National Reform Programme, Convergence Programme and Partnership Agreement which, together with several economically relevant sectoral strategies, constitute the backbone of the strategic cycle up to 2020.

The Government should formulate a national development strategy for the period up to 2020, synchronized with EU $202 \mathrm{O}$ and SEE 2O2O, i.e. with the EU's new multiannual financial framework and financial plan for the use of EU funds up to 2020. The strategy should set forth the goals, priorities and activities arising from the EU strategic processes, especially EU 2020, which should be integrated with Croatia's own strategic development priorities, further elaborated under the sectoral strategies. The national development strategy, if consistently implemented, will have a positive effect on the mutual alignment of existing sectoral strategy documents and coordination of sectoral policies, and, given an efficient implementation monitoring system, on the achievement of the set targets as well.

2 NEWSLETTER IO2 | INSTITUTE OF PUBLIC FINANCE | To the Government and Parliament ... | Institute of Public Finance 


\section{FinANGIAL GOVERNANCE}

Public debt management. In the period 20I6-25 Croatia will have to pay about HRK 2obn annually in public debt principal and interest (e.g. 6\% of GDP in 20I6). Such levels of debt are difficult to sustain, which even citizens are aware of. Hence, as many as $85 \%$ of Croatian respondents in the European Commission' (Eurobarometer) survey think that the measures aimed at reducing Croatia's budget deficit and public debt cannot be delayed. To control public debt growth, i.e. to reduce public debt, it is necessary to:

- Pass a public debt act and adopt a public debt management strategy, regularly publish reports on the stock of debt and its movements, and ensure that parliamentary debates are held on these issues.

- Establish relationships of trust and ensure effective coordination of fiscal and monetary policy measures and instruments between the Croatian National Bank (CNB) and the Government, i.e. Ministry of Finance, especially with respect to the placement of government bonds, development of public debt markets and any activities and transactions involving government borrowing and financial system liquidity.

- Strengthen the capacity of the Ministry' of Finance's Department of Public Debt Management.

State financial assets management. Despite the considerable financial assets owned by Croatia (especially shares and government stakes in companies), the revenues derived from these assets and proceeds from their privatisation are very low, and are often neutralised by the recapitalisation and rehabilitation processes. In the period 2002-15, total privatization proceeds stood at HRK 15.6bn, and total recapitalisation and rehabilitation expenditures amounted to HRK 8.3bn. In the period 2009-I4, the annual recapitalisation and rehabilitation expenditures even exceeded the proceeds from (the already rare and sporadic) privatisations. It is therefore necessary to:

- Apply, for part of the public infrastructure, concessions and initial public offering models for the sale of companies (to enable quick takeovers by potential investors, and, consequently reduce dependence on state aid).

- Identify actual strategic companies and their public missions which should be consistent with the long-term development strategy.

- Identify the activities of public interest, as opposed to market activities, in order to reduce the need for government subsidies to companies which are capable of operating in the market.

- Keep records and determine the actual value of and manage the financial assets owned by the state and local government units.

- Accelerate the privatisation of companies in which the state and local government units hold stakes, with the main motive to boost productivity and ease pressures on the budget, caused by providing aid to companies and their recapitalisation and rehabilitation.

\section{FISGAL DECENTRALISATION AND RELATIONSHIPS AMONG GENTRAL GOVERNMENT, COUNTIES,} GITIES AND MUNICIPALITIES

Croatia lacks an elaborate decentralisation concept and a regional development strategy; its regional policies are not effectively coordinated and there are no estimates of the economic and fiscal effects of the implementation of relevant legislation. A political consensus is needed to determine the number and optimal size of counties, cities and municipalities, the main purposes of which are to provide public goods and 
services and ensure adequate quality of life to citizens, as well as to implement thorough reforms of the country's territorial and fiscal organisation. Therefore, a new government should take the following steps:

- Ensure public access to high-quality and comprehensive data for research and analysis, necessary for efficient decision-making (e.g. the balance sheets of counties, cities and municipalities or databases on information on tax sharing between government and counties, cities and municipalities).

- Make a clear allocation of functions and set minimum financial standards, by determining the mandatory functions of counties, cities and municipalities, based on the set minimum standards, and functions that can be assumed depending on the available resources.

- Arrange that counties, cities and municipalities are funded primarily from taxes, with direct grants from the state budget provided for decentralised services based on service costs per user, but without allocating tax money for other than primarily fiscal purposes.

- Alleviate fiscal inequalities, subject to clearly defined criteria based on the fiscal and economic capacity assessment.

- Establish cooperation and coordination among ministries, the Croatian Bureau of Statistics and the representatives of counties, cities and municipalities in the regular annual analyses and disclosures of the economic and fiscal positions of counties and the cities and municipalities in their respective territories.

- Provide an insight into the general government budget on the basis of regular annual analyses and disclosures of net users of and net payers into the general government budget, as well as of the effects of government policies on the fiscal and economic positions of counties, cities and municipalities.

- Provide an insight into all transactions within the public sector and ensure that they are regularly monitored and reported on, including all public sector entities (companies, utility companies, local road administrations, etc.), partly or wholly owned by the state, counties, cities or municipalities.

- Set up a publicly accessible database with detailed information on the operations of all companies partly or wholly owned by counties, cities or municipalities.

- Ensure the transfer of ownership and management of assets to counties, cities and municipalities, in order to use the potential of, for example, agricultural land or the land which can be used for tourism development.

- Establish coordination among the associations of counties, cities and municipalities, which will be involved in the decentralisation processes through efficient databases (on assets, finances, budgets and local tax and non-tax revenues).

\section{A COMPREHENSIVE APPROAGH TO THE TAX SYSTEM}

A comprehensive tax reform instead of partial changes in the tax system. Despite the thorough tax reform carried out in the mid-I99os, the tax system has, in the meantime, gone through numerous changes, caused by pressures from interest groups and government's need to finance the ever-growing expenditures. As a result, it has become too complex and inefficient, with a high incidence of tax evasion. It is necessary to:

- Conduct an extensive analysis of the tax system and identify its weaknesses, taking into account the economic theory and its findings concerning the effects of tax on income distribution and on the supply of and demand for labour, savings and capital. 
- Include in the analysis economic, social and demographic conditions, as every change may result in a better financial position for some people, but a worse one for others: various types and forms of taxation have different effects on people, depending on their age, the level and structure of income, their having children or not, employment status and activity status (active or retired).

- Explain to the public the comprehensive and adjusted plans and proposals for changes in all areas of the tax system, to ensure a compromise on the distribution of the tax burden and minimise the adverse tax effects. Once they are accepted, it is necessary to ensure the implementation and permanent monitoring of the reform.

Changes in the tax revenue structure. The aforementioned cumulative fall in real GDP since end2008 and consistently low employment rate are the main indicators of the bad shape of Croatian economy. Moreover, low goods exports (about $24 \%$ of GDP in 20I4) and low coverage of goods imports by goods exports (about 60\% in 2014) are clear signs of inadequate export competitiveness of the economy. Therefore, within a thorough, well-planned and comprehensive tax system reform, avoiding any partial interventions into the system, the structure of tax revenues should be focused on boosting competitiveness in the following manners:

- Labour costs should be cut by reducing personal income tax and social security contributions, in order to stimulate demand for labour and employment growth, increase price competitiveness and, consequently, encourage economic growth. In this respect, reducing employer contributions is a more desirable alternative to reducing income tax and employee contributions, because this produces more direct effects on labour costs and demand for labour.

- The revenue loss due to contribution cuts should be offset primarily by reductions on the expenditure side of the budget and by introducing new or increasing the existing taxes, which is considered less detrimental to economic growth (e.g. real estate tax, inheritance and gift tax, consumption tax and environmental taxes). It should be noted, however, that the opportunities to increase tax revenues are limited, given the already relatively high levels of consumption and environmental taxes, and the fact that the expected revenues from real estate tax, if accompanied by abolishing utility charges, are not significant.

- Real estate tax cannot be introduced without thorough preparations and creating the necessary preconditions. It should be determined upfront what kinds of real estate will be taxed and according to which criterion (utility or ability to pay), who determines the tax base and rates (government or local government units), what will be the amount of expected revenues and who they will belong to, taking account of the collection costs. The tax should by all means be progressive, so that the higher the economic capacity of the taxpayer, the heavier the relative tax burden. In the event of the simultaneous abolishment of utility charges (which constitute earmarked revenues of local government units), it should be made sure in advance that the introduction of the tax (as the general-purpose revenue of local government units) does not jeopardize the funding of local utility services.

Value added tax and excise duties. VAT is the most important tax revenue (accounting for about $63 \%$ of total central budget revenue in the period 2OII-I4). Therefore, even the slightest change in the system may have serious effects on the level of national tax revenues. There is some room for revenue increase in excise duties, given that the Croatian minimum excise duty on cigarettes is one of the lowest in the EU and that raising the excise duty rates on cigarettes led to continuous revenue growth (e.g. from HRK 3.3bn in 2OIO to HRK 3.9bn in 2OI4). The following recommendations are proposed to cut budget deficit:

- Given that VAT accounts for over one half of government's total tax revenues, the general VAT rate should not be reduced as long as there is budget deficit. Although the rate is not the only factor 
influencing the tax revenues, increasing the general VAT rate from $23 \%$ to $25 \%$ induced a VAT revenue increase as large as HRK 3.3bn in 2012. It is only after the implementation of reforms in other areas that employment can pick up, the economy can recover and GDP can increase, which would, together with reducing the share of government spending in GDP, provide a basis for a cut in the general VAT rate over a certain period of time.

- The justifiability of the current reduced VAT rates should be examined, without extending the list of products and services subject to reduced rates, because this would result in revenue erosion, make it difficult to accurately define taxable products, increase the possibility of tax evasion and raise the administrative costs of taxation. In short, the tax system would be even more complex, expensive and inefficient. Despite the great number of factors affecting the revenues, introducing new, reduced rates in 2013 led to a slump in VAT revenues of HRK I.65bn.

- Possibilities for raising excise duties on cigarettes should be examined for fiscal, but also health reasons. But, of course, there is a risk of a rise in tax evasion, which necessitates a detailed preliminary effect analysis.

Uncollected taxes. According to data provided by the Tax Administration, HRK 2Ibn remained outstanding in August 2015: HRK 8.8bn in taxes (of which HRK 5bn in VAT), and HRK I2bn in contributions. According to the State Audit Office, over 90\% of VAT and corporate income tax and about $70 \%$ of pension and health insurance contributions for 2014 remained uncollectible. The Tax Administration should establish and disclose the amounts of disputable and obsolete tax and contribution arrears, write them off and focus on the collection of recoverable debts, while taking measures to prevent new debts.

Unregistered work is widespread in Croatia and, in order to combat it, focus should be shifted from its consequences to its causes. It is therefore necessary to:

- Boost public confidence in institutions, primarily through stronger anti-corruption efforts, increased budget transparency, more intensive public participation in budget processes and improving the quality of public services.

- Rectify institutional weaknesses by increasing the independence and efficiency of inspection and judicial bodies. This would ensure equitable and consistent implementation of current measures and provide a basis for the efficient enforcement of future measures to prevent unregistered work.

- Raise public awareness about the disadvantages of unregistered work and the lack of legal protection in the cases of purchasing goods and services on "the black market", publicly stigmatize tax fraud, increase the tax literacy of citizens and generally educate citizens about the importance of taxes for the economy and society as a whole.

- Eliminate economic and administrative causes of unregistered work, by increasing the profitability of work, introducing new forms of work, alleviate the rigidity of labour legislation and adjusting the educational system to the labour market needs.

Tax expenditures (tax exemptions, relief and deductions, as well as tax base or tax liability reductions) are numerous and they are actually budget revenue losses arising from a privileged tax status of certain taxpayers or economic activities. The government uses them for achieving certain economic and social effects, but they violate the basic principles of taxation (equality, fairness, adequacy, efficiency, stability and effectiveness). Tax expenditures are not subject to the same control system as that used for other public expenditures, and are therefore usually introduced without a cost-benefit analysis. So far, there has been no official information in budget documents on tax expenditures and their effects, except the figure "4.I\% of GDP" for 20I4, mentioned in a Ministry of Finance's presentation. Hence, it is necessary to establish and regularly update a register of tax expenditures, as well as continuously analyse and review 
their effectiveness. Reports on tax expenditures should be included in budget documents and regularly audited by the State Audit Office.

Non-tax levies are a great burden on the economy and citizens. In 20I4, they stood at HRK 8.4bn (almost two thirds of that amount came from businesses and one third from citizens), which is more than the total collected corporate income tax revenues (HRK 5.7bn) and only slightly less than the amount collected from personal income tax (HRK IO.5bn). In order to examine the justifiability and effectiveness of these levies, it is necessary to complete and regularly update the register of non-tax levies and rationalize the number and amounts of non-tax levies. The latter can be achieved through the parallel implementation of the reforms of public administration, judiciary and local and regional selfgovernment, public company restructuring and the sale of shares and stakes in companies that are not of strategic national interest.

\section{Public inVESTMENTS}

Public investments stood at about HRK 2obn (roughly 6\% of GDP) in 20I4. The bad thing is that there is no public capital investment programme, with clearly defined goals, priorities and sources of funding, or the missions of public companies and their performance indicators. Therefore, the Government should:

- Prepare an overview of public investments realised so far, broken down by sources of funding, to include all capital projects funded from county, city and municipality budgets and the budgets of extra-budgetary users, the projects of public companies, companies owned by local and regional self-government units and other state-owned institutions.

- Strengthen the capacity of the Ministry of Finance's Capital Investment Department to be able to evaluate and approve all publicly financed projects.

- Approve and finance those long-term capital investment projects that comply with the national strategic development priorities and the already mentioned EU 2020 strategy.

\section{STATE AID}

State aid (financial support provided by government to companies in the form of subsidies, tax incentives, tax debt forgiveness, guarantees, etc.) is an industrial policy instrument by which certain companies or industrial sectors are placed in a privileged position. In 2013, Croatian state aid to industry and services (excluding that to agriculture) was three times the EU average (I.2\% vs. $0.4 \%$ of GDP); the share of sectoral aid (which is the most distortive to market competition) was markedly larger than that in the $\mathrm{EU}$ ( $63 \%$ vs. IO\%), while the share of horizontal aid, regarded as more effective, was considerably below that in the $\mathrm{EU}(37 \%$ vs. 90\%). It is therefore necessary to:

- Reduce the total amount of state aid, while allocating aid for horizontal purposes (R\&D, environmental protection, professional improvement, employment, etc.) rather than to particular sectors.

- Reformulate the industrial policy, i.e. restructure public companies (especially Croatian Railways), continue the privatisation and restructuring of shipyards and avoid giving repeated support to the rehabilitation and restructuring of commercially unviable companies.

- Set up a state aid efficiency monitoring system. 
- Establish and publish a register of state aid, to give an insight to all providers and recipients of aid, other public bodies and the general public into the companies receiving state aid from multiple sources, companies on which the taxpayers' money is spent and the amounts spent.

\section{PENSION SYSTEM}

The Croatian pension system encourages early retirement and it abounds in inequalities. Its long-term expected average pension-to-average wage ratio is among the lowest in the EU, which enhances the risk of poverty in old age. While it is difficult to strike a balance between a fiscally sustainable pension system and adequate benefits in an environment of growing public debt and economic slowdown, it is still possible to take certain measures to improve the pension system, such as:

- Relieving the pension system's burden on the national budget, by further discouraging early retirement, reducing pensions granted under special regulations and their adjustment with regular pensions, reforming the rights related to "hazardous and difficult" occupations, pegging the lowest pension to income status, analysing the contributions-to-benefits relationship in respect of self-employed persons, facilitating the equalization of male and female retirement ages and increasing employment opportunities for elderly workers through lifelong learning and more flexible labour contracts.

- Taking account of the pension system's role in redistribution of income, by analysing the redistributive character of the first pillar of the pension system, considering the possibility of extending the pension supplement to insured persons within the individual capitalised saving scheme, collecting and analysing data on all pension benefits provided at the local level, in order to equalize the benefits across the country.

- Recognizing the importance of the second and third pension pillars, primarily by setting up a system for measuring the efficiency of the second pillar funds management, testing the effectiveness of government incentives for the third pillar pension scheme, and promoting financial literacy of citizens to raise their awareness of responsibility for income in old age.

\section{TRANSPARENCY AND GITIZEN PARTIGIPATION IN FISGAL POLICY AND BUDGET PROGESSES}

As fiscal policy and budgets affect citizens' lives, they must be transparent in order to be analysed and discussed in a reasoned manner. This is the only way to achieve social objectives in accordance with citizens' wishes and the capacities of government, counties, cities and municipalities. Transparency and participation improve political and economic decision-making, ensure more effective provision of public goods and services and reduce opportunities for corruption. Hence, it is necessary to:

- Continuously improve the fiscal policy and national budget transparency, increase opportunities for citizen participation by providing information on fiscal policy and the essentials of budgets and budgeting. Key budget documents should be regularly published in accordance with a legally prescribed calendar and best practices recommended by relevant institutions (e.g. IMF, WB and OECD), including citizens guides to each of the key budget documents.

- Continuously improve the budget transparency of counties, cities and municipalities, and increase opportunities for citizen participation, by obliging these units to publish all key budget documents within predefined time limits and imposing sanctions on those which fail to comply with this obligation. Counties, cities and municipalities should be encouraged to compete in budget 
transparency and citizen participation, while improving cooperation between the Government (i.e. Ministry of Finance) and the associations of counties, cities and municipalities.

- Strengthen the role of Parliament, by establishing a highly professional and efficient parliamentary office for budget and fiscal policy analysis to support MPs but also citizens, and by giving the right to vote to external members of parliamentary committees.

SELEGTED PAPERS OF THE INSTITUTE OF PUBLIC FINANGE SPEGIFICALLY DEALING WITH THE AFOREMENTIONED TOPICS

\section{STRATEGY}

Formulation of strategic development priorities of the Republic of Croatia

\section{Public DebT MANAGement}

A fiscal governance improvement plan for a future Croatian Government Public Sector Finance Management in Croatia

Everything is like last year - we do not have the public debt management strategy?

Changes of methodological coverage of public debt and budget deficit in Croatia

Where is your borrowing and public debt management strategy, gentlemen?

The debt and fiscal risks of local and regional self-government units in Croatia

The cost of government borrowing and yields on Croatian government bonds

Fiscal reforms and consolidations in Croatia under Excessive Deficit Procedure

\section{STATE FINANGIAL ASSETS MANAGEMENT}

Croatian Institute of Immunology: where have things got stuck?

Audit of local government-owned companies

Finally, a state asset management plan in Croatia

Government guarantees and financial liabilities of state owned road transport companies in Croatia

Institutional Framework for Government Asset Management in Croatia

\section{FISGAL DECENTRALISATION AND RELATIONSHIPS AMONG GENTRAL GOVERNMENT, COUNTIES, GITIES AND MUNICIPALITIES}

Net fiscal positions of counties in Croatia from 2011 to 2013

The effects of decentralisation in Croatia on the economic and fiscal position of the Istria County (in Croatian)

Budget outturns of Croatian municipalities, cities and counties for 2014

Budget transparency in Croatian counties, cities and municipalities (November 2OI4 - March 20I5) 
Fifteenth amendments to the Local Government Unit Financing Act

Restructuring of public companies - the key to successful public sector reforms in Croatia Non-profit, private or public?

Package of legislative amendments for a better Croatian regional policy

Inefficiency of Revenue Collection in Local Government Units in Croatia

\section{TAX SYSTEM}

The impact of changes in the Personal Income Tax Act on the average tax rate

Supports for households with children

A new Croatian Decree on the amounts of excise duty on petrol, gas oil and kerosene used as propellants Tax reforms in EU member states

Employment and employment characteristics during the current crisis in Croatia

Has Croatia reached the tax maximum?

An immovable property tax proposal in Croatia: some open issues

Ten Reasons in favour of a uniform rate of a Value Added Tax

The structure of excise duties on cigarettes in the Republic of Croatia

Excise duties system in Croatia closer to the European system

Changes in the Value Added Tax System

Collected and Uncollected Taxes in Croatia and in the European Union

Hidden public consumption: the present and future of tax expenditures (in Croatian)

\section{NON-TAX LEVIES}

Solidarity charge - a new non-tax levy

Financial Report of the Croatian National Tourist Board without financial statements

Are differences in water prices economically justified?

\section{Public investments}

Capital investment plans and local government debt in Croatia

\section{STATE AID}

Who gets state aid in Croatia?

Eight Findings about the 20Io State Aid in Croatia

Government guarantees and financial liabilities of state owned road transport companies in Croatia

The debt and fiscal risks of local and regional self-government units in Croatia

Zagreb Holding: Time for restructuring

What will happen to state aid in Croatia after EU accession?

EU-I2: State aid before and after EU accession

IO NEWSLETTER Io2 | INSTITUTE OF PUBLIC FINANCE | To the Government and Parliament ... | Institute of Public Finance 
Industrial Policy and State Aid in Croatia

\section{Pension System}

European Commission's opinion on the Croatian Pension System

The purposes of personal saving and borrowing

Management costs of Ist and 2nd pillar retirement insurance institutions in Croatia

Why are there so many disability pensions beneficiaries in Croatia?

Pension beneficiaries who have been granted pensions under more favourable conditions

\section{TRANSPARENCY AND GITIZEN PARTIGIPATION IN FISGAL POLIGY AND BUDGET PROGESSES}

Local budget transparency

Budget outturns of Croatian municipalities, cities and counties for 2014

Budget transparency in Croatian counties, cities and municipalities (November 2OI4 - March 20I5)

Citizen Participation in Fiscal Policy and Budgetary Processes in Croatia

IMF: Code of Fiscal Transparency (in Croatian)

National budget transparency - a deterioration in the quality and comprehensiveness of government revenue and expenditure information

New IMF Code of Fiscal Transparency: Citizens should be involved in fiscal decision-making

Public participation in fiscal policy and budget processes in Croatia

NEWSLETTER IO2 | INSTITUTE OF PUBLIC FINANCE ｜ To the Government and Parliament ... I Institute of Public Finance II 